\title{
Inflammatory markers, sarcopenia and its diagnostic criteria among the elderly: a systematic review
}

Karen Mello de Mattos Margutti

Natielen Jacques Schuch ${ }^{2}$

Carla Helena Augustin Schwankel

\section{Abstract}

Objective: To identify the relationship between inflammatory markers and sarcopenia, and the diagnostic criteria of the condition among the elderly. Methods: A systematic review was performed based on the consultation of the PubMed and LILACS databases. Eligible original articles were those involving individuals aged 60 years or more, which investigated sarcopenia [low muscle mass (MM) associated with poor muscle strength and/or reduced physical performance, according to the European Working Group on Sarcopenia in Older People consensus (EWGSOP)] or its diagnostic criteria, published in English or Portuguese, between 2010-2015. Results: Four articles were included in the review, the principle results of which were: the growth differentiation factor (GDF-15) exhibited a negative correlation with MM, handgrip strength and gait speed; the insulin-like growth factor-1 (IGF-1) correlated positively with MM; follistatin exhibited a weak correlation with physical performance; activin A and myostatin did not correlate with the diagnostic criteria; the highest tercile of extracellular heat shock protein 72 (eHsp72) was associated with lower median levels of MM, handgrip strength and gait speed; elderly persons with low MM had higher serum ferritin concentrations; women with low MM exhibited lower serum concentration levels of C-reactive protein (CRP). Conclusion: the six investigated inflammatory markers (GDF-15, IGF-1, follistatin, eHsp72, ferritin and CRP) were associated with the diagnostic criteria for sarcopenia, but not with sarcopenia itself. As research in this area is still developing, additional studies are required to broaden knowledge and eventually establish the role of these markers in the diagnosis and management of sarcopenia.

\footnotetext{
Pontifícia Universidade Católica do Rio Grande do Sul (PUCRS), Instituto de Geriatria e Gerontologia, Programa de Pós-Graduação em Gerontologia Biomédica. Porto Alegre, RS, Brasil.

2 Centro Universitário Franciscano, Curso de Nutrição, Programa de Pós-Graduação em Ciências da Saúde e da Vida. Santa Maria, RS, Brasil.
}

Research funding: Program of Academic Excellence of the Coordination for the Improvement of Higher Education Personnel (PROEX-CAPES). Type of support: research grant.

Keywords: Biomarkers. Elderly. Sarcopenia. 


\section{INTRODUCTION}

The aging process is triggered by physiological changes which occur distinctly among individuals and their organic systems. One of these changes is the change in body composition, where there is an increase in fat mass and visceral fat and an involuntary reduction of muscle mass ${ }^{1}$. According to the European Consensus on the definition and diagnosis of sarcopenia of the European Working Group on Sarcopenia in Older People (EWGSOP) ${ }^{2}$, sarcopenia is a geriatric syndrome characterized by low muscle mass associated with low muscle strength and/ or poor physical performance. This syndrome is associated with adverse outcomes such as functional disability (dependence) ${ }^{2,3}$, low quality of life ${ }^{3}$ and the risk of death ${ }^{2}$.

The existence of these criteria makes it possible to diagnose three distinct stages of sarcopenia: pre-sarcopenia, when there is low muscle mass; sarcopenia, when there is low muscle mass associated with low muscle strength and/or low physical performance; and severe sarcopenia, when there is inadequacy in the three diagnostic criteria ${ }^{2,4}$.

There are several mechanisms involved in the genesis and evolution of sarcopenia, including neuroendocrine factors (such as insulin-like growth factor 1 (IGF-1), insulin resistance), age-related factors (sexual hormones, apoptosis, mitochondrial dysfunction), inadequate nutrition/malabsorption, disuse (immobility, physical inactivity, zero severity) and neurodegenerative diseases (loss of motor neurons) $)^{2,3}$. Inflammation is another factor involved ${ }^{1,3}$. Studies have indicated the deleterious effects of inflammatory markers on muscle quantity, quality and functionality,

The inflammatory process results from changes in the anabolic and catabolic mediators. The decline in serum concentrations of anabolic hormones such as testosterone, growth hormone $(\mathrm{GH})$, insulin and IGF-1 causes muscle catabolism. The reduction in GH and IGF-1 decreases the recruitment of satellite cells into the muscle tissue and protein synthesis. Consequently, there is increased production of inflammatory mediators such as pro-inflammatory cytokines, and inflammatory markers produced by hepatocytes that accelerate the process of muscle catabolism. In contrast, with the increased production of these inflammatory mediators, there is a reduction in anti-inflammatory mediators ${ }^{4,7-9}$.

Despite knowledge of the role of inflammation in sarcopenia, studies on this topic and the relationship between inflammatory markers and the diagnostic criteria for sarcopenia among the elderly population are still incipient. Such research can contribute to a better understanding of the pathophysiology, diagnosis and management of sarcopenia.

Thus, the present article aims to identify, through a systematic review, the relationship between inflammatory markers and sarcopenia and its diagnostic criteria in the elderly.

\section{METHODS}

This systematic review was carried out in accordance with the recommendations proposed by the Preferred Reporting Items for Systematic Reviens and Meta-Analyses (PRISMA) ${ }^{10}$, and it was registered in the International Prospective Register of Systematic Reviews (PROSPERO) under number CRD42015017926.

The eligibility criteria were original articles published in the period 2010-2015 in English or Portuguese, which addressed the relationship between inflammatory markers and sarcopenia and its diagnostic criteria in elderly persons with an age group of 60 years or older. Articles that did not evaluate the presence of sarcopenia (low muscle mass associated with low muscle strength and/or low physical performance) or its diagnostic criteria (muscle mass, strength and/or physical performance) as recommended by the European Consensus on the definition and diagnosis of sarcopenia of the EWGSOP ${ }^{2}$ were excluded. Articles published from January to April 2010 were excluded because they were prior to the aforementioned Consensus ${ }^{2}$. Experimental studies with animals, in vitro studies, recommendations, guidelines, reviews, protocols, letters, editorials and case reports were also excluded.

The search strategies and sources were directed at articles included in the PubMed and Lilacs electronic databases, from January to February of 2016, with the last search carried out on $02 / 13 / 2016$. For this process, the descriptors of the Medical Subject Headings (Mesh) and their correlates in Portuguese 
of the Descriptors in Health Sciences (DeCS) were used: sarcopenia; aged; older and elderly; biomarker and biomarkers and biologic marker and biologic markers. The descriptors inflammatory; inflammatory marker and inflammatory markers; inflammatory biomarker and inflammatory biomarkers and inflammatory cytokines, which were not included in the Mesh and the DeCS but were widely cited in articles, were also used. In order to widen the search the key words biomarkers: serum marker and serum markers described in the Mesh were inserted. The above descriptors and key words were used independently or combined with the aid of the conjunctions: AND and OR and the truncated term sarcopen ${ }^{*}$. The search sequence was: [(inflammatory OR biomarker OR biomarkers OR biologic marker OR biologic markers OR inflammatory marker OR inflammatory markers OR inflammatory biomarker OR inflammatory biomarkers OR serum marker OR serum markers OR inflammatory cytokines) AND (sarcopenia OR sarcopenias OR sarcopeni*) AND (aged OR older OR elderly)]. The filters used in the searches were: studies in humans published in the last six years.

The initial selection of articles was carried out by two independent reviewers who evaluated the suitability of the articles from the information provided in the title and abstract. Subsequently, the same reviewers evaluated the complete texts of the articles and made the final selection, according to the established criteria, on an independent basis. For registration, a standardized form was used, through which the authors independently extracted the following data: author(s); year of publication; study design; population (gender, place of recruitment, age/age range, sample size, country of study); objective; methods for measuring diagnostic criteria for sarcopenia; inflammatory markers evaluated; synthesis of main results regarding sarcopenia; conclusion of the study; studies with sarcopenia and/or studies involving the diagnostic criteria of sarcopenia. In cases of divergences in the selection of article(s), the third author also read the text and opted for the inclusion or exclusion of the same(s).

The quality and risks of bias of the articles included in the review were analyzed through the Strengthening the Reporting of Observational Studies in Epidemiology (STROBE) ${ }^{11}$ which evaluates the quality of observational studies through 22 criteria. The STROBE was translated into Portuguese and validated by Malta et al. ${ }^{12}$. For the scoring of the articles the methodology of Mendes et al..$^{13}$, where each of 22 criteria receives a score of 0 to 1 , was used. After evaluating all the criteria, each article received a score of 0 to 22 from each reviewer and the final grade was obtained from the mean. The score was transformed into a percentage, with articles with a percentage superior to $50 \%$ considered of good quality.

\section{RESULTS}

Figure 1 shows the article selection flowchart in detail. As can be seen, 154 articles were initially identified, of which only four, all in English, were included in the systematic review.

Table 1 presents the absolute and relative scores of the quality of the four articles identified from the criteria established by STROBE for observational studies. All the articles achieved a percentage superior to $50 \%$, being considered of good quality and thus were included in the present review. 


Articles identified in PubMed $(\mathrm{n}=132)$
\begin{tabular}{|l|}
\hline Articles excluded following reading of titles and \\
abstracts in PubMed $(\mathrm{n}=125)$ \\
- Without sarcopenia descriptor $=26$ \\
- Without markers descriptor $=26$ \\
- Without descriptor elderly $=20$ \\
- Review articles $=46$ \\
- Guidelines/Protocols/Recommendations $=04$ \\
- Studies with animals $=02$ \\
- Articles in other language $=01$ (Japanese)
\end{tabular}

Articles identified in Lilacs $(n=22)$

Articles excluded following reading of titles and abstracts in Lilacs $(n=22)$

- Without markers descriptor $=01$

- Without descriptor elderly $=01$

- Review articles $=08$

- Guidelines/Protocols/Recommendations $=0$

- Studies with animals $=01$

- Duplicate articles from PubMed $=10$

- Articles in other language=01 (Japanese)

Figure 1. Flowchart of study selection. Santa Maria, Rio Grande do Sul, 2016.

Table 1: Score and quality percentage of included in accordance with STROBE. Santa Maria, Rio Grande do Sul, 2016.

\begin{tabular}{|c|c|}
\hline \multirow{2}{*}{ Author(s)/year of publication } & Quality of articles \\
\hline & Score $(\%)$ \\
\hline Hofmann et al., $2015^{14}$ & $18.5(84.09)$ \\
\hline Ogawa et al., $2012^{15}$ & $18.4(83.63)$ \\
\hline Chung et al., $2013^{16}$ & $19.1(86.81)$ \\
\hline Santos et al., $2014^{17}$ & $18.8(85.45)$ \\
\hline
\end{tabular}

Regarding the outline of the included articles, all were observational studies, with one prospective ${ }^{14}$ and three cross-sectional ${ }^{15-17}$.

All the articles included described the relationship between inflammatory markers and the diagnostic criteria for sarcopenia. Hofmann et al. ${ }^{14}$ and Ogawa et al. ${ }^{15}$ evaluated this relationship with the three diagnostic criteria (muscle mass, muscular strength and physical performance) while
Chung et al. ${ }^{16}$ and Santos et al. ${ }^{17}$ used the criterion of muscle mass. Only Hofmann et al. ${ }^{14}$ evaluated this relationship with sarcopenia diagnosed according to the EWGSOP.

To evaluate muscle mass (MM), Hofmann et al. ${ }^{14}$ and Ogawa et al. ${ }^{15}$ used bioelectrical impedance analysis (BIA) as an instrument for assessing body composition, while Chung et al. ${ }^{16}$ and Santos et al. ${ }^{17}$ used Dual Energy X-ray (DEXA). 
Muscle strength was assessed in two studies by the evaluation of hand grip strength (HGS) using dynamometry ${ }^{14,15}$. In addition to HGS, Hofmann et al. ${ }^{14}$ verified muscle strength from isokinetic knee extension force using the Knee at $60^{\circ}$ Isokinetic Peak Torque Test (PTE).

Physical performance was assessed by Hofmann et al. ${ }^{14}$, using the Gait Speed Test (GS), the Six-Minute Walk Test and the Chair Stand Test. Ogawa et al. ${ }^{15}$ used the GS test.

Eight inflammatory markers associated with sarcopenia and/or its diagnostic criteria were analyzed: growth differentiation factor (GDF-15); Insulin-like growth factor-1 (IGF-1); Follistatin; Activin A; and Myostatin, which make up the transforming growth factor beta (TGF- $\beta$ ) superfamily, in the study by Hofmann et al. Extracellular heat shock protein 72 (eHsp72) was analyzed by Ogawa et $\mathrm{al}^{15}$; Ferritin was evaluated in the study by Chung et al. ${ }^{16}$ and C-reactive protein (CRP) was investigated by Santos et al. ${ }^{17}$. Ogawa et al. ${ }^{15}$ also analyzed interleukin-6 (IL-6) combined with eHsp72 and its association with HGS.

In the study by Hofmann et al. ${ }^{14}$, higher serum concentrations of GDF-15 and lower IGF-1 were found among elderly women regardless of whether they were classified as sarcopenic or non-sarcopenic. A significant correlation between GDF-15 and all the diagnostic criteria of sarcopenia, MM, muscle strength (HGS) and physical performance (SixMinute Walk Test and GS) was also verified. IGF-1 and follistatin presented, respectively, a correlation only with the MM criteria and physical performance, evaluated by the Chair Stand Test. Activin A and myosin did not correlate with any of the diagnostic criteria for sarcopenia. No single or combined marker, meanwhile, reflected sarcopenia.

The study by Ogawa et al. ${ }^{15}$ found that serum levels of eHsp72 were associated with all the diagnostic criteria for sarcopenia (low MM assessed by BIA, low muscle strength assessed by HGS, low physical performance assessed by GS), regardless of gender, age and incidence of pathologies, and a higher risk for low HGS when there were combined medium and high serum concentrations of IL- 6 and eHsp72 adjusted for gender and age.

In the study by Chung et al. ${ }^{16}$, elderly persons with low appendicular skeletal muscle mass (ASSM) had higher serum ferritin concentrations, although there was only a statistically significant difference among men. Santos et al. ${ }^{17}$ found a correlation between CRP and fat free appendicular mass (FFAM) and higher serum concentrations of CRP in the elderly with low FFAM.

The characteristics of the articles, as well as the synthesis of the main results, are described in Chart 1. 


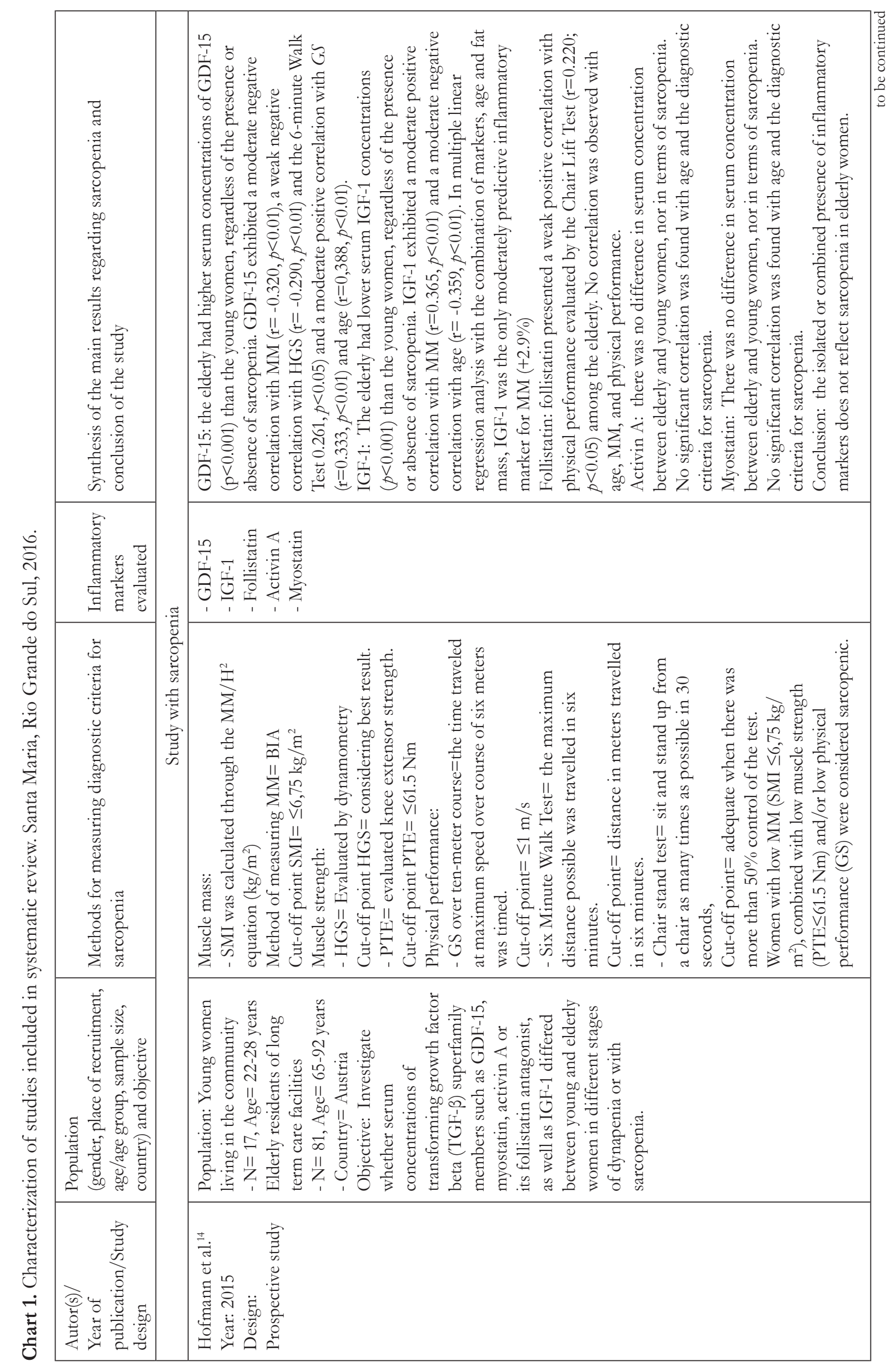




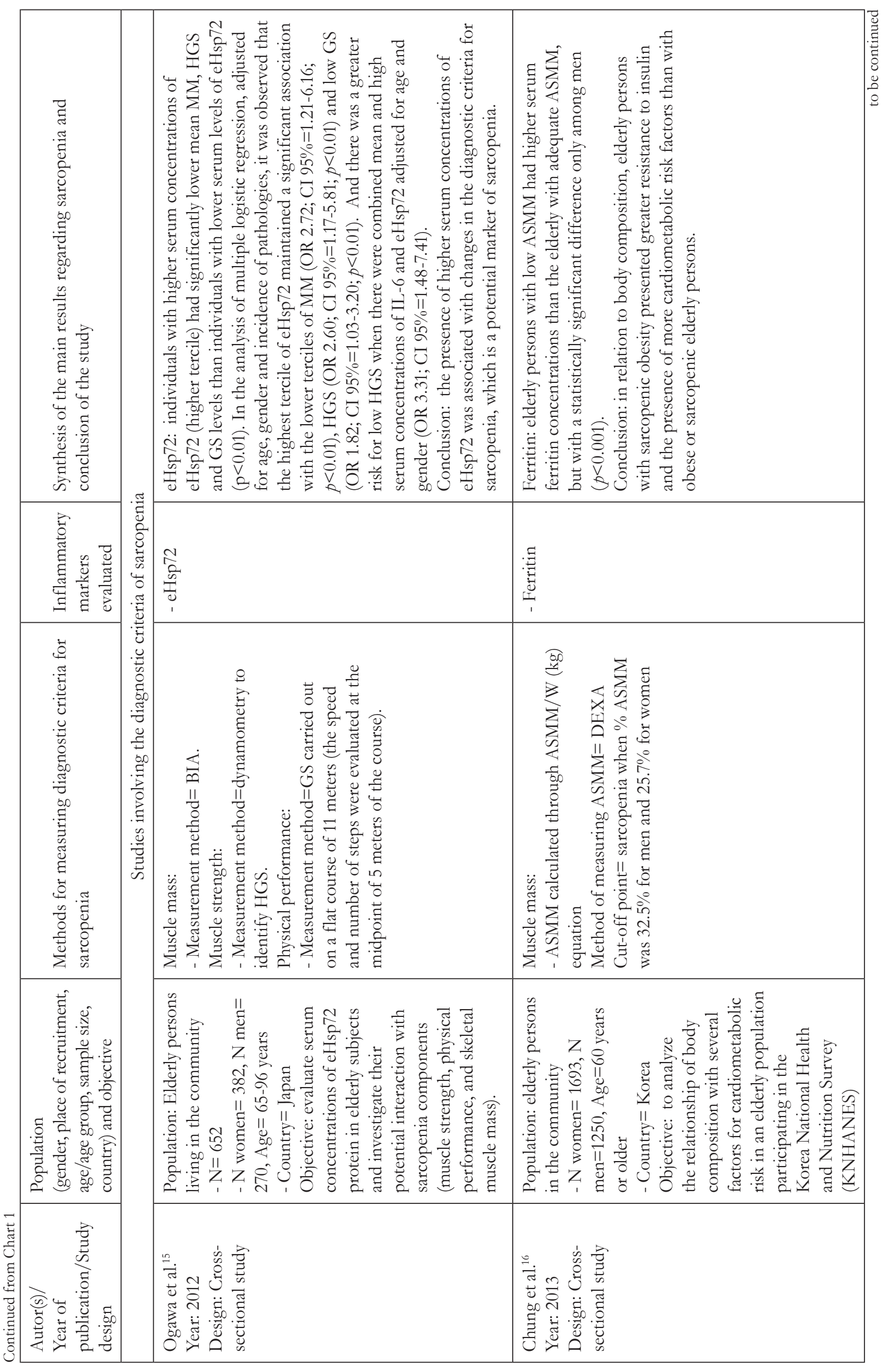




\begin{tabular}{|c|c|c|}
\hline 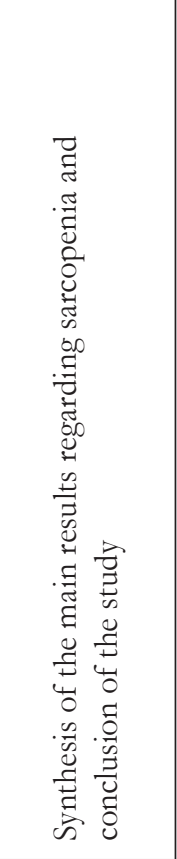 & 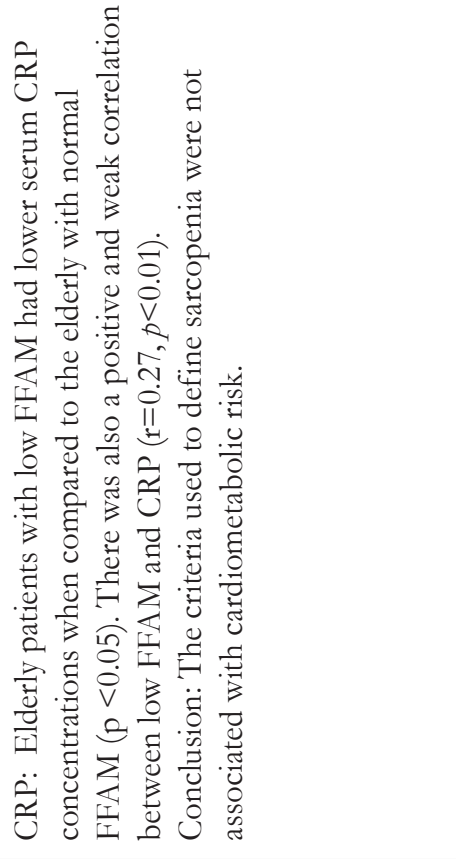 & \\
\hline 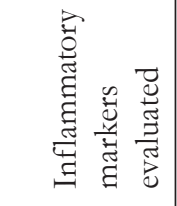 & ب̂: & \\
\hline 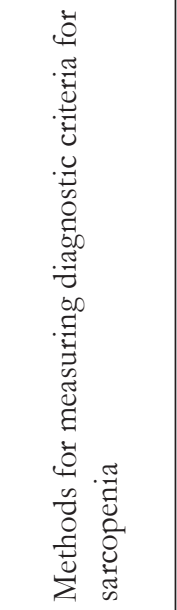 & 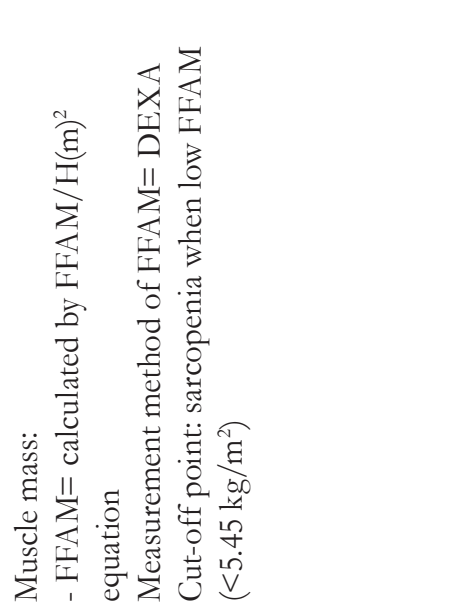 & \\
\hline 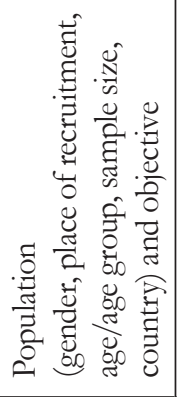 & 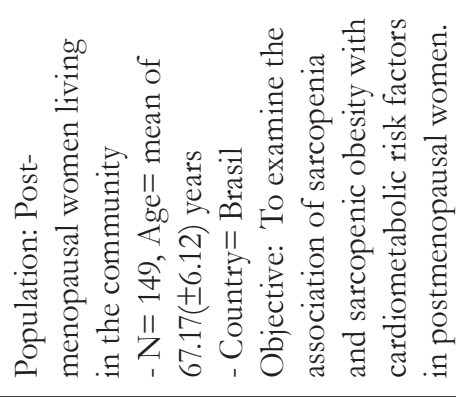 & \\
\hline 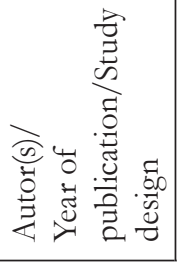 & 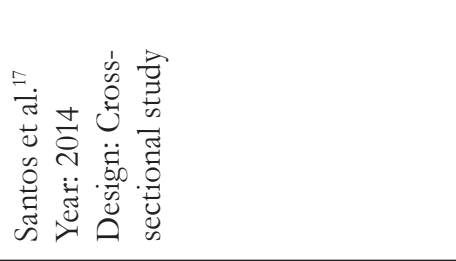 & \\
\hline
\end{tabular}




\section{DISCUSSION}

The present article presents a systematic review of the relationship of inflammatory markers with sarcopenia and/or its components. Only four original articles that tackle this issue were identified, emphasizing the incipient nature of the theme. In this review, it was observed that only the study by Hofmann et al. ${ }^{14}$ analyzed the association of inflammatory markers with sarcopenia (diagnosed according to the EWGSOP) ${ }^{2}$. The researchers included five markers in their analyzes: GDF-15 $5^{14}$, IGF-14 ${ }^{14}$, follistatin ${ }^{14}$, activin $\mathrm{A}^{14}$, and myostatin ${ }^{14}$. None of these markers were associated with sarcopenia. Ogawa et al. ${ }^{15}$, Chung et al. ${ }^{16}$, Santos et al. ${ }^{17}$ and Hofmann et al. ${ }^{14}$ investigated the association of inflammatory markers with the diagnostic criteria for sarcopenia, and identified eight inflammatory markers (eHsp $72^{15}$, ferritin ${ }^{16}, \mathrm{CRP}^{17}, \mathrm{GDF}-15^{14}$, IGF-14 ${ }^{14}$, follistatin ${ }^{14}$, activin $\mathrm{A}^{14}$ and myostatin ${ }^{14}$ ). Of these, it was verified that six markers (eHsp $72^{15}$,

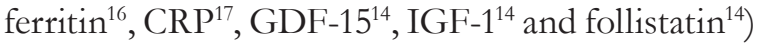
exhibited an association with the diagnostic criteria for sarcopenia.

Regarding the quality of the articles, according to the STROBE criteria, the observational studies included presented percentages over $80 \%$, which reflect their high quality, as the STROBE instrument assists in verifying the methodological transparency of a study ${ }^{11}$.

The cytokine TGF- $\beta$ and the components of its superfamily (activin A, myostatin, GDF-15 and follistatin), IGF-1 protein and the chemokine eHsp72, act in the immunologic system ${ }^{18}$, in stress ${ }^{19}$, in lymphoproliferative disorders ${ }^{20}$ and especially in the inflammatory process ${ }^{19,21,22}$. They are considered markers of the inflammatory process of chronic non-communicable diseases such as heart disease ${ }^{20}$, rheumatoid arthritis ${ }^{18,22}$, systemic sclerosis ${ }^{18}$ and osteoarthrosis ${ }^{18}$.-

GDF-15 is poorly produced by the tissues, but its excessive production causes deleterious effects directly on muscle, which results in the reduction of muscle mass ${ }^{23}$. Bloch et al. ${ }^{19}$ observed the association between higher serum concentrations of GDF-15 and the reduction of muscle mass in a study of elderly patients in intensive care. These results reinforce those obtained by Hofmann et al. ${ }^{14}$ who found a negative correlation between GDF-15 and muscle mass, HGS and gait speed $(p<0.01)$.

IGF-1 acts as a positive regulator of muscular growth ${ }^{23}$. However, the aging process triggers the decline of IGF-16. Hofmann et al. ${ }^{14}$ verified that elderly women, regardless of whether they were classified as sarcopenic or non-sarcopenic had lower serum IGF-1 concentrations $(p<0.01)$ than young women. Follistatin, an antagonist of activin $A$ and myostatin, as well as IGF-1, also acts as a positive regulator of muscle growth ${ }^{23}$. Activin A and myostatin, meanwhile, when excreted excessively, cause muscular atrophy and impairment, respectively, in muscle regeneration ${ }^{23}$. Hofmann et al. ${ }^{24}$ when carrying out resistance training with 41 elderly women evaluated at the beginning and at the third and the sixth month of training, observed that higher serum follistatin concentrations were associated with longer training times $(p=0.008)$, but found no changes in the serum concentrations of activin $\mathrm{A}$ and myostatin. These results are similar to those found by Hofmann et al. ${ }^{14}$.

At high concentrations EHsp72 reflects the level of cellular stress that contributes to a decrease in muscle mass ${ }^{21}$. Ogawa et al. ${ }^{15}$ observed the association between increased eHsp72 and low muscle mass. Similarly, Perreault et al. ${ }^{21}$, in a study with 26 elderly subjects undergoing 16 weeks of physical training, found that the reduction of serum concentrations of eHsp72 increased the amount of muscle mass $(p=0.03)$, due to the decrease of the inflammatory process.

The association between the higher serum concentrations of the inflammatory markers GDF-15 and eHsp72 and low HGS, investigated by Hofmann et al. ${ }^{14}$ and Ogawa et al. ${ }^{15}$, respectively, corroborate with the results of Baylis et al. ${ }^{25}$, which found an association between greater Inflammatory load and low HGS ( $p=0.001)$. Ogawa et al. ${ }^{15}$ reported a higher risk for low HGS among elderly persons (OR 3.31, CI $95 \%=1.48-7.41)$ with combined medium and high serum concentrations of eHsp72 and IL-6. IL-6 is considered one of the most important inflammatory mediators in the aging process and is positively 
correlated with a reduction of lean mass ${ }^{26}$, functional decline $^{26}$ and mortality ${ }^{26}$. A study by PuzianowskaKuźnicka et al. ${ }^{27}$ with 3,496 elderly persons, found that serum IL- 6 concentrations increase with age and are associated with poorer physical performance and greater cognitive deficit $(p<0.001)$.

Ferritin, considered an acute phase protein, is involved in the systemic inflammatory process ${ }^{28}$ and oxidative stress ${ }^{29}$. Similar to Chung et al. ${ }^{16}$, who observed higher serum ferritin concentrations among sarcopenic elderly persons, Kim et al. ${ }^{30}$, when evaluating the association between serum ferritin and sarcopenia in 952 men and 1380 elderly women (60 years and older), also identified the presence of higher serum ferritin concentrations among sarcopenic women $(p<0.001)$.

Higher serum concentrations of CRP are associated with disability and mortality, an increased risk of low muscle strength, and are correlated with lower muscle mass in older individuals ${ }^{31-33}$. Legrand et al. ${ }^{34}$, in a study with 567 elderly persons, found that high CRP values were associated with a low score in the Short Physical Performance Battery (SPPB) that evaluates physical performance.

It should be noted that elderly individuals with preserved muscle mass may present alterations in inflammatory markers. This is because inflammaging (the chronic and low-grade systemic inflammation common in aging) is due to changes in the immune system, inflammatory mediators, changes in body composition (increase in adipose tissue), and acute and chronic diseases that independently increase the inflammatory markers ${ }^{35}$.

\section{REFERENCES}

1. Pícoli TS, De Figueiredo LL, Patrizzi LJ. Sarcopenia e envelhecimento. Fisioter Mov [Internet]. 2011[acesso em 21 jan. 2016];24(3):455-62. Disponível em: http:// www.scielo.br/scielo.php?script=sci_arttext\&pid =S0103-51502011000300010

2. Cruz-Jentoft AJ, Baeyens JP, Bauer JM, Boirie Y, Cederholm T, Landi F, et al. Sarcopenia: European consensus on definition and diagnosis: report of the European Working Group on Sarcopenia in Older
Finally, the use of different methods and cut-off points to diagnose and measure the diagnostic criteria for sarcopenia can be considered limiting factors of this systematic review, which may overestimate or underestimate the prevalence of the same. Another limiting factor was the populational heterogeneity of the studies, with populations composed of men and women in different countries, which made it impossible to ascertain the inflammatory profile of a specific population.

\section{CONCLUSION}

Four articles were included in this systematic review. Only one evaluated sarcopenia diagnosed in accordance with the EWGSOP Consensus.

None of the five inflammatory markers studied (GDF-15, IGF-1, follistatin, activin A and myostatin) were found to be associated with sarcopenia.

Of the eight inflammatory markers studied (GDF-15, IGF-1, follistatin, activin A, myostatin, eHsp72, ferritin and CRP), only two (activin A and myostatin) were not associated with the diagnostic criteria for sarcopenia.

In this context, the scarcity of studies on the relationship between inflammatory markers and sarcopenia and its diagnostic criteria points out the need for further research on the subject, in order to contribute to a deeper understanding of the pathophysiological mechanisms of sarcopenia, as well as the establishment of inflammatory markers in the diagnosis, intervention and accompanying of this condition.
People. Age Ageing [Internet]. 2010 [acesso em 21 jan. 2016];39(4):412-23. Disponível em: https://www. ncbi.nlm.nih.gov/pubmed/20392703

3. Diz JBM, Queiroz BZ, Tavares LB, Pereira LSM. Prevalência de sarcopenia em idosos: resultados de estudos transversais amplos em diferentes países. Rev Bras Geriatr Gerontol [Internet]. 2015 [acesso em 21 jan. 2016];18(3):665-78. Disponível em: http://www. scielo.br/scielo.php?script $=$ sci_arttext\&pid=S1809$98232015000300665 \& \operatorname{lng}=$ pt\&nrm=iso\&tlng=en 
4. Zembroń-Łacny A, Dziubek W, Rogowski L, Skorupka E, Dabrowska G. Sarcopenia: Monitoring, molecular mechanisms, and physical intervention. Physiol Res [Internet]. 2014 [acesso em 07 fev. 2016];63(6):683-91. Disponível em: https://www.ncbi. nlm.nih.gov/pubmed/25157651

5. Cristi C, Collado PS, Márquez S, Garatachea N, Cuevas MJ. Whole-body vibration training increases physical fitness measures without alteration of inflammatory markers in older adults. Eur J Sport Sci [Internet]. 2013 [acesso em 21 jan. 2016];14(6):19. Disponível em: https://www.ncbi.nlm.nih.gov/ pubmed/24237186

6. Hubbard RE, O’Mahony MS, Savva GM, Calver BL, Woodhouse KW. Inflammation and frailty measures in older people. J Cell Mol Med [Internet]. 2009 [acesso em 21 jan. 2016];13(9B):3103-9. Disponível em: https://www.ncbi.nlm.nih.gov/ pubmed/19438806

7. Kim JK, Choi SR, Choi MJ, Kim SG, Lee YK, Noh $\mathrm{JW}$, et al. Prevalence of and factors associated with sarcopenia in elderly patients with end-stage renal disease. Clin Nutr [Internet]. 2014 [acesso em 07 fev. 2016];33(1):64-8. Disponível em: https://www.ncbi. nlm.nih.gov/pubmed/23631844

8. Pierine DT, Nicola M, Oliveira EP. Sarcopenia : alterações metabólicas e consequências no envelhecimento. Rev Bras Ciênc Mov [Internet]. 2009 [acesso em 08 fev. 2016];17(3):96-103. Disponível em: https://portalrevistas.ucb.br/index.php/RBCM/ article/viewFile/999/1409

9. Brito CJ, Volp ACP, Nóbrega OT, Silva Júnior FL, Mendes EL, Roas AFCM, et al. Exercício físico como fator de preveção aos processos inflamatórios decorrentes do envelhecimento. Motriz Rev Educ Fís [Internet]. 2011 [acesso em 10 mar. 2017];17(3):544-55. Disponível em: http:// www.scielo.br/scielo.php?script=sci_arttext\&pid $=$ S1980-65742011000300017

10. Moher D, Liberati A, Tetzlaff J, Altman DG; PRISMA Group. Preferred Reporting Items for Systematic Reviews and Meta-Analyses: the PRISMA Statement (Reprinted from Annals of Internal Medicine). Phys Ther [Internet]. 2009 [acesso em 21 jan. 2016];89(9):873-80. Disponível em: http://annals. org/aim/article/744664/preferred-reporting-itemssystematic-reviews-meta-analyses-prisma-statement
11. Von Elm E, Altman DG, Egger M, Pocock SJ, Gotzsche PC, Vandenbroucke JP. Strengthening the Reporting of Observational Studies in Epidemiology (STROBE) statement: guidelines for reporting observational studies. BMJ [Internet]. 2007 [acesso em 13 fev. 2016];335(7624):806-8. Disponível em: https://www.ncbi.nlm.nih.gov/pubmed/17947786

12. Malta M, Cardoso LO, Bastos FI, Magnanini MMF, Silva CMFP. Iniciativa STROBE: subsídios para a comunicação de estudos observacionais. Rev Saúde Pública [Internet]. 2010 [acesso em 17 fev. 2016];44(3):559-65. Disponível em: http:// www.scielo.br/scielo.php?script=sci_arttext\&pid $=$ S0034-89102010000300021

13. Mendes KG, Theodoro H, Rodrigues AD, Olinto MTA. Prevalência de síndrome metabólica e seus componentes na transição menopáusica: uma revisão sistemática. Cad Saúde Pública [Internet]. 2012 [acesso em 17 fev. 2016];28(8):1423-37. Disponível em: http://www.scielo.br/scielo.php?script $=$ sci_ arttext\&pid=S0102-311X2012000800002

14. Hofmann M, Halper B, Oesen S, Franzke B, Stuparits $\mathrm{P}$, Tschan $\mathrm{H}$, et al. Serum concentrations of insulinlike growth factor-1, members of the TGF-beta superfamily and follistatin do not reflect different stages of dynapenia and sarcopenia in elderly women. Exp Gerontol [Internet]. 2015 [acesso em 13 fev. 2016];64:35-45. Disponível em: https://www.ncbi. nlm.nih.gov/pubmed/25681638

15. Ogawa K, Kim H, Shimizu T, Abe S, Shiga Y, Calderwood SK. Plasma heat shock protein 72 as a biomarker of sarcopenia in elderly people. Cell Stress Chaperones [Internet]. 2012 [acesso em 13 fev. 2016];17(3):349-59. Disponível em: https://www.ncbi. nlm.nih.gov/pmc/articles/PMC3312957/

16. Chung JY, Kang HT, Lee DC, Lee HR, Lee YJ. Body composition and its association with cardiometabolic risk factors in the elderly: a focus on sarcopenic obesity. Arch Gerontol Geriatr [Internet]. 2013 [acesso em 13 fev. 2016];56(1):270-8. Disponível em: https://www.ncbi.nlm.nih.gov/pubmed/23079031

17. Santos EP, Gadelha AB, Safons MP, Nóbrega OT, Oliveira RJ, Lima RM. Sarcopenia and sarcopenic obesity classifications and cardiometabolic risks in older women. Arch Gerontol Geriatr [Internet]. 2014 [acesso em 13 fev. 2016];59:56-61. Disponível em: https://www.ncbi.nlm.nih.gov/pubmed/24766993 
18. Chaly Y, Hostager B, Smith S, Hirsch R. Follistatinlike protein 1 and its role in inflammation and inflammatory diseases. Immunol Res [Internet]. 2014 [acesso em 17 fev. 2016];59(1-3):266-72. Disponível em: https://www.ncbi.nlm.nih.gov/ pubmed/24838142

19. Bloch SAA, Lee JY, Syburra T, Rosendahl U, Griffiths MJD, Kemp PR, et al. Increased expression of GDF-15 may mediate ICU-acquired weakness by down-regulating muscle microRNAs. Thorax [Internet]. 2015 [acesso em 17 fev. 2016];70(3):21928. Disponível em: https://www.ncbi.nlm.nih.gov/ pubmed/25516419

20. Wojciechowska C, Wodniecki J, Wojnicz R, Romuk E, Jachéc W, Tomasik A, et al. Neopterin and beta-2 microglobulin relations to immunity and inflammatory status in nonischemic dilated cardiomyopathy patients. Mediat Inflamm [Internet]. 2014 [acesso em 17 fev. 2016];1-8. Disponível em: https://www.ncbi.nlm.nih.gov/pubmed/25214716

21. Perreault K, Courchesne-Loyer A, Fortier M, Maltais M, Barsalani R, Riesco E, et al. Sixteen weeks of resistance training decrease plasma heat shock protein 72 (eHSP72) and increase muscle mass without affecting high sensitivity inflammatory markers' levels in sarcopenic men. Aging Clin Exp Res [Internet]. 2016 [acesso em 17 fev. 2016];28(2):207-14. Disponível em: https://www.ncbi.nlm.nih.gov/pubmed/26197717

22. Phillips DJ, Kretser DM, Hedger MP. Activin and related proteins in inflammation: Not just interested bystanders. Cytokine Growth Factor Rev [Internet]. 2009 [acesso em 17 fev. 2016];20(2):153-64. Disponível em: https://www.ncbi.nlm.nih.gov/pubmed/19261538

23. Kalinkovich A, Livshits G. Sarcopenia: the search for emerging biomarkers. Ageing Res Rev [Internet]. 2015 [acesso em 21 jan. 2016];22:58-71. Disponível em: https://www.ncbi.nlm.nih.gov/ pubmed/25962896

24. Hofmann M, Schober-Halper B, Oesen S, Franzke B, Tschan H, Bachl N, et al. Effects of elastic band resistance training and nutritional supplementation on muscle quality and circulating muscle growth and degradation factors of institutionalized elderly women: the Vienna Active Ageing Study (VAAS). Eur J Appl Physiol [Internet]. 2016 [acesso em 10 mar. 2017];116(5):885-97. Disponível em: https:// www.ncbi.nlm.nih.gov/pmc/articles/PMC4834098/

25. Baylis D, Ntani G, Edwards MH, Syddall HE, Bartlett DB, Dennison EM, et al. Inflammation, telomere length, and grip strength: a 10-year longitudinal study. Calcif Tissue Int [Internet]. 2014 [acesso em 07 jan. 2016];95(1):54-63. Disponível em: https://www.ncbi.nlm.nih.gov/pubmed/24858709
26. Santos MLAS, Gomes WF, Pereira DS, Oliveira DMG, Dias JMD, Ferrioli E, et al. Muscle strength, muscle balance, physical function and plasma interleukin-6 (IL-6) levels in elderly women with knee osteoarthritis (OA). Arch Gerontol Geriatr [Internet]. 2011 [acesso em 13 fev. 2016];52(3):322-6. Disponível em: https://www.ncbi.nlm.nih.gov/pubmed/20627334

27. Puzianowska-Kuźnicka M, Owczarz M, Wieczorowska-Tobis K, Nadrowski P, Chudek J, Slusarczyk P, et al. Interleukin- 6 and C-reactive protein, successful aging, and mortality: the PolSenior study. Immun Ageing [Internet]. 2016 [acesso em 07 jul. 2016];13(1):1-12. Disponível em: https:// www.ncbi.nlm.nih.gov/pmc/articles/PMC4891873/ pdf/12979_2016_Article_76.pdf

28. Oh IH, Choi EY, Park J-S, Lee CH. Association of serum ferritin and kidney function with age-related macular degeneration in the general population. PLoS One [Internet]. 2016 [acesso em 07 jul. 2016];11(4):111. Disponível em: https://www.ncbi.nlm.nih.gov/ pmc/articles/PMC4838228/pdf/pone.0153624.pdf

29. Lu CH, Allen K, Oei F, Leoni E, Kuhle J, Tree $\mathrm{T}$, et al. Systemic inflammatory response and neuromuscular involvement in amyotrophic lateral sclerosis. Neurol Neuroimm Neuroinflamm [Internet]. 2016 [acesso em 07 jul. 2016];3(4):111. Disponível em: https://www.ncbi.nlm. nih.gov/pmc/articles/PMC4897985/pdf/ NEURIMMINFL2015008474.pdf

30. Kim TH, Hwang HJ, Kim SH. Relationship between serum ferritin levels and sarcopenia in korean females aged 60 years and older using the fourth korea national health and nutrition examination survey (KNHANES IV-2, 3), 2008-2009. PLoS One [Internet]. 2014 [acesso em 28 fev. 2016];9(2):2008-9. Disponível em: www.ncbi.nlm.nih.gov/pubmed/24587226

31. Meng Y, Wu H, Yang Y, Du H, Xia Y, Guo X, et al. Relationship of anabolic and catabolic biomarkers with muscle strength and physical performance in older adults: a population-based cross-sectional study. BMC Musculoskelet Disord [Internet]. 2015 [acesso em 28 fev. 2016];16:1-23. Disponível em: http://bmcmusculoskeletdisord.biomedcentral.com/ articles/10.1186/s12891-015-0654-7

32. Yang CW, Li CI, Li TC, Liu CS, Lin CH, Lin WY, et al. Association of sarcopenic obesity with higher serum high-sensitivity c-reactive protein levels in Chinese older males - A community-based study (Taichung Community Health Study-Elderly, TCHS-E). PLoS One [Internet]. 2015 [acesso em 21 jan. 2016];10(7):1-13. Disponível em: https://www. ncbi.nlm.nih.gov/pubmed/26177029 
33. Schaap LA, Pluijm SMF, Deeg DJH, Harris TB, Kritchevsky SB, Newman AB, et al. Higher inflammatory marker levels in older persons: associations with 5 -year change in muscle mass and muscle strength. J Gerontol [Internet]. 2009 [acesso em 08 fev. 2016];64(11):1183-9. Disponível em: https://www.ncbi.nlm.nih.gov/pubmed/19622801

34. Legrand D, Adriaensen W, Vaes B, Matheï C, Wallemacq P, Degryse J. The relationship between grip strength and muscle mass (MM), inflammatory biomarkers and physical performance in communitydwelling very old persons. Arch Gerontol Geriatr
[Internet]. 2013 [acesso em 08 fev. 2016];57(3):34551. Disponível em: https://www.ncbi.nlm.nih.gov/ pubmed/23830056https://www.ncbi.nlm.nih.gov/ pubmed/23830056

35. Piovezan R, Ribeiro S. Inflammaging: inflamação sistêmica e de baixo grau decorrente do envelhecimento. Rio de Janeiro: Sociedade Brasileira de Geriatria e Gerontologia; 2016 [acesso em 10 mar. 2017]. Módulo 1. Disponível em: http://sbgg.org. br/wp-content/uploads/2014/11/18761A-Separata_ Inflammaging.pdf 